проаналізувати досвід американської системи освіти щодо програми «Виховання характеру» та розпочати впроваджувати іiї у навчальний процес.

Перспективу подальших наукових пошуків убачаємо в цілісному дослідженні наявних програм «Виховання характеру», визначаючи слабкі та сильні аспекти кожної.

\title{
Література
}

1. About the YMCA: History of the YMCA Movement. (n.d.). YMCA: We build strong kids, strong families, strong communities. Retrieved April 12, 2008. [Electronic source]. - Mode of access: http://www.ymca.net 2. Hymowitz K. S. (2003, Spring). The return of character education. Public Interest, 151, 104-109. 3. Lickona T. (1993, November). The return of character education. Educational Leadership, 51(3), 6-11. 4. Macleod D. (1983). Building character in the American boy: The Boy Scouts, YMCA, and their forerunners, 1870-1920. Madison, WI: The University of Wisconsin Press. 5. Reese W. J. (2007). History, education, and the schools. New York: Palgrave Macmillan. 6. Stock-Morton P. (1988). Moral education for a secular society: The development of Morale Laique in nineteenth century France. Albany, NY: State University of New York Press. 7. The Boy Scouts of America. (2008). Boy Scouts of America: National Council. Retrieved April 12, 2008. [Electronic source]. - Mode of access: http://www.scouting.org 8. Webber J. A. (2003). Failure to hold: The politics of school violence. Lanham, MD: Rowman \& Littlefield. 9. William Holmes McGuffey and his readers. (1993, January). [Brochure]. National Park Service, U.S. Department of the Interior.10. Wilson H. E. (1938). Education for citizenship: Report of the Regents' Inquiry. York, PA: Maple Press.

УДК $378.016: 37.015 .31$

Стешенко В. В., Мусаєв К. Ф., Белікова М. В.

\section{ЗАРОДЖЕННЯ ТА СТАНОВЛЕННЯ МЕТОДИЧНОЇ ПІДГОТОВКИ МАЙБУТНІХ КЕРІВНИКІВ ДИТЯЧОЇ ТЕХНІЧНОЇ ТВОРЧОСТІ У ХХ СТОЛІТТІ}

Стешенко В.В., Мусаєв К. Ф., Белікова М. В. Зародження та становлення методичної підготовки майбутніх керівників дитячої технічної творчості у ХХ столітті.

Показано особливості зародження та становлення методичної підготовки майбутніх керівників технічної творчості учнів у процесі позакласної та позашкільної роботи. Установлено, що необхідність пї започаткування викликана бурхливим розвитком науково-технічного прогресу на початку та в середині XX ст. Розкрито закладені науковцями-педагогами основи підготовки відповідних спеціалістів, яких почали готувати у вишах з числа майбутніх учителів праці (трудового навчання).

Ключові слова: учитель праці, методичні посібники, технічна творчість учнів, позакласна і позашкільна робота.

Стешенко В. В., Мусаев К.Ф., Беликова М. В. Зарождение и становление методической подготовки будущих руководителей детского технического творчества в XX веке.

Показаны особенности зарождения и становления методической подготовки будущих руководителей технического творчества учащихся в процессе внеклассной и 
внешкольной работы. Установлено, что необходимость ее основания была вызвана бурным развитием научно-технического прогресса в начале и в средине XX ст. Раскрыты заложенные учеными-педагогами основы подготовки соответствующих специалистов, которых стали готовить у ВНЗ с числа будущих учителей труда (трудового обучения).

Ключевые слова: методические пособия, техническое творчество учащихся, учитель труда, внеклассная и внешкольная работа.

Steshenko V. V., Musayev K.F., Belikova M. V. Genesis and formation of future children's technical creativity leaders' methodical training in the XX-th century.

Peculiarities of genesis and formation of future pupils' extracurricular technical creativity leaders' methodical training are described in the article. The need for its foundation is proved to be caused by the rapid development of scientific and technical progress in the beginning and in the middle of the twentieth century. The authors reveal the basics of future specialists training which were laid down by scientists and educators.

Key words: manuals, pupils' technical creativity, labour training teacher, extracurricular work.

Залучення учнів загальноосвітніх шкіл до позашкільної та позакласної роботи 3 техніки в нашій країні розпочалося в період становлення оновленої школи в 20-х рр. минулого століття. Виникнення цього руху пов'язане з бурхливим розвитком науково-технічної революції, що викликало в населення, зокрема в учнівської молоді, сплеск інтересу до наукових і технічних знань і стало поштовхом до створення в школах різного типу технічних гуртків. До керівництва такими гуртками та станціями юних техніків, які були спеціально створені для цього, спочатку залучали передових робітників і техніків, які хоч і не мали спеціальної освіти, а частіше й вищої, але 3 покладеними на них обов'язками справлялися успішно. Згодом до керівництва гуртками почали залучати фахівців 3 числа інженерів, а також учителів фізики та інших предметів.

Спеціальна методична підготовка фахівців до керівництва технічними гуртками розпочалася не відразу з початком організації технічної творчості учнів. Для іiі становлення потрібні були десятиліття. Щоб забезпечити таку підготовку спеціалістів нині, необхідно виявити особливості ії організації на різних етапах становлення руху із залучення учнів до технічної творчої діяльності.

Окремі питання становлення методичної підготовки майбутніх керівників технічної творчості викладені в роботах І. Білосевича, І Волощука, Г. Левченка, А. Пригодія та інших науковців. Разом 3 цим дослідниками (О. Биковська, С. Васильченко, С. Мартова, В. Мацулевич та ін.) досить докладно розроблені питання становлення підготовки спеціалістів до позакласної й позашкільної роботи 3 учнями. Однак системне наукове вивчення змісту методичної підготовки майбутніх керівників технічної творчості ще не стало предметом окремого дослідження, що й зумовило вибір теми цієї статті.

Mema cmammi: розкрити особливості зародження та становлення методичної підготовки майбутніх керівників технічної творчості учнів у процесі позакласної та позашкільної роботи.

Аналіз психолого-педагогічної літератури показав, що окремі аспекти порушеної нами проблеми педагоги та практики почали розв'язувати відразу із зародженням технічної творчої діяльності учнівської молоді. Так, психологічні основи творчої 
діяльності науковці (Л. Виготський, П. Енгельмейер, А. Лурія, А. Леонтьєв, Ж. Россман, С. Рубінштейн, Т. Рибо, П. Якобсон та ін.) розробляли вже в 20-х - 30-х pp. минулого сторіччя. Разом з цим, на основі розробленого ними психологічного аналізу творчої діяльності практики складали науково обгрунтовані методики організації технічної творчості школярів, які розглядалася не лише як процес, супутній спортивному чи аматорському моделюванню, але й як органічна частина навчально-виховної роботи на уроках і в позакласний час. Зокрема вчителі праці, фізики та хімії на заняттях 3 технічної творчості використовували різноманітні пошукові завдання та лабораторні дослідження, розраховані на більш менш тривалий період їх виконання.

Початок цілеспрямованої методичної підготовки майбутніх керівників технічної творчості до розвитку технічних здібностей учнів слід пов'язати 3 появою відповідних методичних посібників і введенням відповідних дисциплін до змісту професійної підготовки спеціалістів 3 вищою освітою. Хоч керували технічними творчими гуртками переважно техніки та інженери, однак посібники видавалися для вчителів. Так, одним із перших методичних посібників 3 організації позакласної роботи 3 техніки, як і більшість усіх наступних, було видано для вчителів, піонервожатих i позашкільних працівників. Це була книга Ю. Шарова «Позакласна работа 3 техніки» [8], яка вийшла друком у 1955 році. У посібнику автор розкрив завдання позакласної та позашкільної роботи 3 техніки в аспекті політехнічного навчання, педагогічні принципи та організаційні форми, зміст, систему позакласної та позашкільної роботи 3 техніки, а також окремі питання загальної методики позакласної роботи - теорію та практику організації діяльності дітей у гуртку юних техніків, методику навчання учнів практичних умінь і навичок із моделювання, а також підготовки вчителя до позакласних занять тощо. Це була одна 3 перших спроб висвітлення методичних питань, яка мала допомогти вчителям (керівникам гуртків) виважено організувати технічну творчість учнів і зробити іiі одним 3 ефективних засобів виховання та навчання.

У зв'язку 3 прийняттям у державі Закону «Про зміцнення зв'язку школи 3 життям і подальшим розвитком системи народної освіти в країні» увага педагогічної громадськості була звернена на необхідність широкого розвитку в школах технічного винахідництва, розроблення учнями нових приладів, моделей, технічних пристроїв, дослідницької роботи в сільському господарстві. У цей час з'являється книга В. Разумовського [5], у якій було представлено перші спроби системного висвітлення вузлових питань методики організації та розвитку такої діяльності учнів. Викладення відповідної методики навчання починалося 3 розкриття психологічних аспектів дитячої технічної творчості, висвітлення питань про технічну творчість у психологічній літературі, питань іiі організації- вибору та розроблення тематики гурткових занять, постановки та розв'язання творчих задач, здійснення творчого задуму тощо.

У цей же час на державному рівні започаткована професійна підготовка до керівництва технічною творчістю майбутніх учителів. Так, у навчальні плани спеціальності 2120 «Загальнотехнічні дисципліни і праця з додатковою спеціальністю фізика» запроваджено відповідний факультатив - «Практикум 3 моделювання i технічної творчості». Однак навчання студентів обмежувалося оволодінням тільки практичними вміннями та навичками з технічного моделювання, до якого в різних вишах включали моделювання різних об'єктів: чи то літаків, чи то автомобілів, чи то ракет, чи інших яких технічних засобів. 
Певним внеском у становлення методичної підготовки майбутніх керівників технічної творчості з числа вчителів стала книга А. Михайлова «Технічна творчість учнів» [6], призначена для вчителів праці, керівників шкільних технічних гуртків, працівників позашкільних дитячих установ. У книзі висвітлено деякі методичні основи роботи з розвитку дитячої технічної творчості та питання ії організації; розкрито досвід роботи вчителів на уроках праці і в технічних гуртках різного профілю. Особливістю цієї книги було те, що в ній розкривалися не тільки питання форм позашкільної роботи учнів 3 техніки, змісту діяльності школярів 3 технічної творчості, а й представлено процес розвитку в них елементів технічного мислення. Це давало керівникам гуртків можливість усвідомлювати психологічні та педагогічні аспекти технічної творчої діяльності учнів і сприяло більшій результативності цієї роботи.

Згодом, починаючи з 1971 року, у навчальні плани спеціальності 2120 «Загальнотехнічні дисципліни і праця 3 додатковою спеціальністю фізика» було введено - курси за вибором. Факультатив «Практикум з моделювання і технічної творчості» набув нового, більш вагомого статусу. Окрім того, цей курс можна було доповнювати новою навчальною дисципліною «Моделювання та його використання під час розв'язання задач з фізики й техніки». Цей курс належав до дисциплін, які забезпечували наукову підготовку майбутніх учителів фізики і водночас сприяли формуванню в них готовності до формування та розвитку технічного мислення в дітей під час технічної творчості. Але, на жаль, на їх вивчення в кожному вищому навчальному закладі відводили мінімальну кількість годин i не скрізь однакову. Навчальні програми також характеризувалися не зовсім виваженим змістом, який часто визначався кафедрами відповідно до спеціальності викладачів.

Досить грунтовна розробка проблеми методики організації технічної творчості учнів була представлена в 1972 в монографії відомого українського дослідникапедагога Д. Тхоржевського [7]. У роботі автор розкрив сутність технічної творчості та iii значення для всебічного розвитку учнів, визначив можливості трудового навчання для розвитку технічної творчості учнів і розкрив процес технічного моделювання як основний шлях розвитку технічної творчості учнів. Технічну творчість науковець пов'язував із навчанням учнів винахідництву та раціоналізаторству, яке отримало на той час значний розвиток на промислових підприємствах. Також автор визначив особливості дитячої технічної творчої діяльності, умовами якої, вслід за І. Смагіним, назвав створення необхідної обстановки для самостійних дій учнів у процесі праці, підведення їх до творчої ідеї або пряма постановка перед ними творчих питань і завдань, стимулювання до мобілізації й застосування загальнотеоретичних i політехнічних знань для розв'язання творчих завдань, застосування різних педагогічних прийомів стимулювання інтелектуальної активності учнів під час виконання завдань творчого характеру, формування в них таких психологічних та інтелектуальних якостей, які дають людині можливість швидко зорієнтуватися в умовах сучасної техніки (спостережливості, уваги, технічного мислення, позитивних емоційних реакцій) тощо. Науковець також дійшов висновку, що для навчання учнів розв'язання конструкторських і технологічних задач потрібно мати певну систему завдань, яку й запропонував. Але у вищих педагогічних навчальних закладах отримані дослідником результати практично не використовувались.

Потреба в подальшому теоретичному розробленні педагогічних аспектів технічної творчості учнів і задоволення запитів практики 3 реалізації можливостей залучення їх до посильної конструкторсько-технологічної діяльності у процесі 
трудового навчання і виховання зумовила вихід у 1976 році в світ книги за редакцією А. Андріанова «Дидактичні основи розвитку технічної творчості в трудовому навчанні учнів міської школи» [2]. Книга призначена для працівників шкіл і позашкільних установ, науковців, викладачів і студентів педагогічних ВНЗ. Проблеми змісту, організаційних форм і методів розвитку технічної творчості учнів розглядалися в книзі у зв'язку з уявленнями науковців про розвиток здібностей учнів (зокрема й творчих) у процесі конкретної діяльності. Основними засобами формування в них умінь творчої праці в посібнику визначалася конструкторськотехнологічна діяльність на заняттях у шкільних майстернях, у кабінетах із технічних видів праці, розв'язання творчих задач і завдань.

Автори книги спочатку розкрили дидактичні основи технічної творчості (схарактеризували дослідження 3 технічної творчості, витлумачили саме поняття, сутність технічної творчості школярів у процесі трудового навчання), а також дидактичні основи конструкторсько-технологічної діяльності учнів і навчання їх елементів конструювання, зміст конструкторської діяльності у шкільних майстернях, методи та прийоми активізації цієї діяльності. Потім читачам було запропоновано прийоми залучення учнів IX-X класів до творчої діяльності, зміст програм, процес розв'язання учнями творчих завдань на теоретичних заняттях, принципи відбору таких завдань тощо. Ознайомлення з цими питаннями забезпечувало керівникам технічних гуртків свідому організацію процесу творчої технічної діяльності учнів.

Результатом вивчення та розроблення науковцями проблеми стало введення в 1977 році в навчальний посібник «Методика трудового навчання» [4] окремого розділу «Позакласна робота 3 вивчення техніки». Цей розділ передбачав такі підрозділи, як «Завдання позакласної роботи», «Організаційні форми позакласної роботи 3 техніки», «Організація роботи технічних гуртків» тощо. Але, як бачимо 3 назв підрозділів, дидактичні основи організації технічної творчості в посібнику не розкривалися. Однак, починаючи 3 цього часу, методична підготовка студентів до керівництва технічною творчістю учнів стала здійснюватися в педагогічних ВНЗ в межах методичної підготовки вчителя праці (трудового навчання). Хоч це було й найменшим, але виявилося важливим і суттєвим кроком у становленні методичної підготовки майбутніх учителів до керівництва технічною творчістю учнів у процесі позакласної та позашкільної роботи.

Ці книги стали підгрунтям для виконання рішень Постанови партії та уряду 1977 року «Про подальше вдосконалення навчання, виховання учнів загальноосвітніх шкіл i підготовки їх до праці», яка передбачала широке залучення старшокласників до технічної творчості в умовах навчання в навчально-виробничих комбінатах i подальше вдосконалення підготовки майбутніх учителів до цієї діяльності.

Узагальнивши досвід попередників, у 1982 році теоретичні основи змісту підготовки майбутніх учителів трудового навчання до керівництва технічною творчістю учнів виклали А. Василевська та Р. Пономарьова [1] в новому аспекті. Наступного, 1983 року групою авторів під керівництвом В. Колотилова видано навчальний посібник, призначений для студенів спеціальності 2008 «Викладання праці та креслення в IV-VIII класах загальноосвітньої школи» [3]. Укладачі посібника наголошували на тому, що інтенсивний розвиток технічної творчості учнів вимагав відповідної підготовки кваліфікованих педагогічних кадрів, здатних розвивати в дітей елементи творчості. Разом з цим вони визначили систему професійних умінь, якими повинні володіти керівники гуртків. На цьому етапі становлення методики професійної підготовки майбутніх учителів трудового навчання до керівництва 
технічною творчістю учнів у процесі позакласної та позашкільної роботи можна вважати закінченим, оскільки науковці та практики почали переходити до системного розроблення іiі змісту в світлі основних положень реформи загальноосвітньої та професійної школи 1984 року.

Отже, на основі викладеного вище можемо стверджувати, що зародження та становлення методичної підготовки майбутніх керівників технічної творчості учнів у процесі позакласної та позашкільної роботи здійснювалося довгих 50 років. Необхідність виконання такої роботи була зумовлена посиленням інтересу учнівської молоді до технічної творчості, який був викликаний бурхливим розвитком науки, техніки та технологій як на початку, так і в середині XX століття. Методичні розробки були адресовані вчителям фізики, хімії, праці, але професійна підготовка таких керівників у вишах здійснювалася з числа майбутніх учителів праці. У цей період науковці й педагоги заклали основи відповідної галузі науки та іiї запровадження в навчальний процес.

Подальші пошуки в окресленому напрямі пов'язані з вивченням особливостей методичної підготовки майбутніх керівників технічної творчості учнів у процесі позакласної та позашкільної роботи на наступному етапі.

\section{Література}

1. Василевская А. М. Развитие технического творческого мышления у подростков и юношества / А. М. Василевская, Р. А. Пономарева. - К : Вища школа, 1982. - 144 с. 2. Дидактические основы развития технического творчества в трудовом обучении учащихся городской школы / [под. ред. А. Н. Андрианова]. - М. : НИИ ТО ПО АПН СССР, 1976. - 188 с. З. Колотилов В. В. Техническое моделирование и конструирование : [учеб. пособ. для студ. пед. ин-тов] / В. В. Колотилов, В. А. Рузаков, Ю. И. Иванов и др.; под общ. ред. В. В. Колотилова. - М. : Просвещение, 1983. - 255 с. 4. Методика трудового обучения: [учеб. пособ. для учащихся пед. училищ по специальности № 2008 «Преподавание труда и черчения в IV-III кл. общеобразоват. школы»]/ под ред. Д. А. Тхоржевского. - М. : Просвещение, 1977. - 287 с. 5. Разумовский В. Г. Развитие технического творчества учащихся / В. Г. Разумовский. - М. : Учпедгиз, 1961. - 128 с. 6. Техническое творчество школьников / сост. А. А. Михайлов. - М. : Просвещение, 1969.- 208 с.

7. Тхоржевський Д. О. Дидактика трудового навчання : [монографія]/ Д. О. Тхоржевський. - К. : Рад. шк., 1972. - 224 с. 8. Шаров Ю. В. Внеклассная работа по технике : [метод. пособие для учителей, пионервожатых и внешкольных работников, ведущих работу с юными техникам] / Ю. В. Шаров. - М. : Учпедгиз, 1955. $-87 \mathrm{c}$.

\section{Наталія Хорошилова}

\section{ФОРМИ НАВЧАННЯ ІНОЗЕМНИХ МОВ У СИСТЕМІ ОСВІТИ ДОРОСЛИХ ФРН}

Хорошилова Н. В. Форми навчання іноземних мов у системі освіти дорослих ФРН.

У статті розглянуто специфіку альтернативних 3 позиції організації форм навчання іноземних мов у ФРН, до яких відносять інтенсивне, заочне та навчання через засоби масової інформації.

Ключові слова: інтенсивне навчання, альтернативне навчання, автономне 